\title{
Diffuse systemic sclerosis with bullous lesions without systemic manifestations*
}

\author{
Esclerose sistemica difusa bolhosa sem acometimentos sistemicos
}

\author{
Paula Renaux Wanderley Caratta Macedo ${ }^{1}$ \\ Alexandre Carlos Gripp ${ }^{2}$ \\ Evandro Mendes Klumb ${ }^{4}$
}

\begin{abstract}
Amanda Nascimento Cavalleiro de Macedo Mota ${ }^{1}$
Maria de Fatima Guimarães Scotelaro Alves ${ }^{3}$
\end{abstract}

DOI: http://dx.doi.org/10.1590/abd1806-4841.20132160

\begin{abstract}
Here, we describe an atypical case of systemic sclerosis in its diffuse cutaneous form with acute and rapid progression of the cutaneous condition, without any systemic manifestations and the infrequent formation of bullae, showing the importance of diagnosis and early treatment in such cases. This case also shows that special measures should be taken for bullous cutaneous lesions and ulcerations resulting from serious sclerosis, which are entry points and increase morbidity and risk of death. Other prognostic factors include age, ESR and renal and pulmonary involvement. Capillaroscopies can be useful predictors of greater severity of systemic scleroderma, revealing a greater link with systemic, rather than cutaneous, involvement.

Keywords: Connective tissue diseases; Scleroderma, diffuse; Scleroderma, systemic; Skin diseases, vesiculobullous; Skin and connective tissue diseases
\end{abstract}

Resumo: Descrevemos um caso atípico de esclerose sistêmica em sua forma cutânea difusa com instalação aguda e rápida progressão do quadro cutâneo sem qualquer acometimento sistêmico e a infrequente formação de bolhas, demostrando a importância do diagnóstico e tratamento precoce frente a casos semelhantes e mostrando, com a experiência deste caso, que cuidados especiais devem ser tomados com as lesões cutâneas bolhosas e as ulcerações decorrentes da grave esclerose que são portas de entrada e aumentam a morbidade e risco de morte. Outros fatores prognósticos descritos são idade, VHS e envolvimento pulmonar e renal. A capilaroscopia pode ser preditor de maior gravidade da esclerodermia sistêmica, guardando maior relação com o envolvimento sistêmico do que cutâneo.

Palavras-chave: Dermatopatias vesiculobolhosas; Doenças da pele e do tecido conjuntivo; Doenças do tecido conjuntivo; Esclerodermia difusa; Escleroderma sistêmico

\section{INTRODUCTION}

Systemic sclerosis, in its diffuse cutaneous form, is characterized by an initial edematous phase, giving rise to cutaneous thickening of centrifugal evolution, often without any vasospastic phenomena. This form of the disease typically spares the nipples and manifests with diffuse hyperpigmentation, bearing a similar color to that found in adrenal insufficien$\mathrm{cy}^{1,2}$ In most cases, it manifests with esophageal, pulmonary, renal or cardiac, involvement. Almost no predilection by sex has been noted.

\section{CASE REPORT}

Male, aged 61, presenting cutaneous sclerosis involving acute onset, progressive evolution, of centrifugal character, for 3 months, associated with functional limitation of joint movements and oral opening. The dermatological exam revealed hyperpigmentation and diffuse cutaneous thickening, sparing the nipples, an increase in hand volume without any vasospastic phenomena or sclerodactyly, and tense bullous lesions in the lower limbs (Figures 1,2 and 3). He did not present comorbidity, was a smoker and

Received on 26.09.2012.

Approved by the Advisory Board and accepted for publication on 17.01.2013.

* Work carried out at the Pedro Ernesto University Hospital - State University of Rio de Janeiro (HUPE-UERJ) - Rio de Janeiro (RJ), Brazil.

Conflict of interest: None

Financial funding: None

Resident doctor in dermatology at the Pedro Ernesto University Hospital - State University of Rio de Janeiro (HUPE-UERJ) - Rio de Janeiro (RJ), Brazil. Master's in dermatology from the Federal Fluminense University (UFF). Assistant professor of dermatology at the State University of Rio de Janeiro (UERJ) Rio de Janeiro (RJ), Brazil.

PhD in dermatology from the Federal University of Rio de Janeiro (UFRJ). Adjunct professor of dermatology at the State University of Rio de Janeiro (UERJ) - Rio de Janeiro (RJ), Brazil.

Master's in medical sciences - Adjunct professor of reumatology, Faculty of Medical Sciences - State University of Rio de Janeiro (FCM-UERJ) - Reumatologist of the Pedro Ernesto University Hospital - State University of Rio de Janeiro (RJ), Brazil.

C2013 by Anais Brasileiros de Dermatologia 
social drinker, and worked as a general assistant. He presented no exposure to chemical products like vinyl chloride, silica, etc. Additional tests did not reveal abnormalities, except for elevated ESR and ANA 1:320 with fine speckled cytoplasmatic pattern, negative results for rheumatoid factor, anti-topoisomerase, anti-centromere and anti-RNP. Capillaroscopy of the nail bed with hairpin-shaped capillary loops, without pathological megacapillaries, ramifications or intersections, corresponding to discrete microcirculatory changes of nonspecific character. The histopathological analysis showed an area of intense subepidermal edema, forming multiocular bullae, moderate perivascular mononuclear infiltrate, collagen compression, incarceration of annexes and lymphangiectasias (Figures 4 and 5). Colloidal iron staining was weakly positive for mucin in the dermis. Given the rapid evolution of the disease, treatment was started using cyclophosphamide $1 \mathrm{~g} / \mathrm{kg} / \mathrm{month}$ and prednisone. In outpatient follow-up, after 5 cycles, there was partial improvement in the cutaneous sclerosis, without any specific organic involvement.

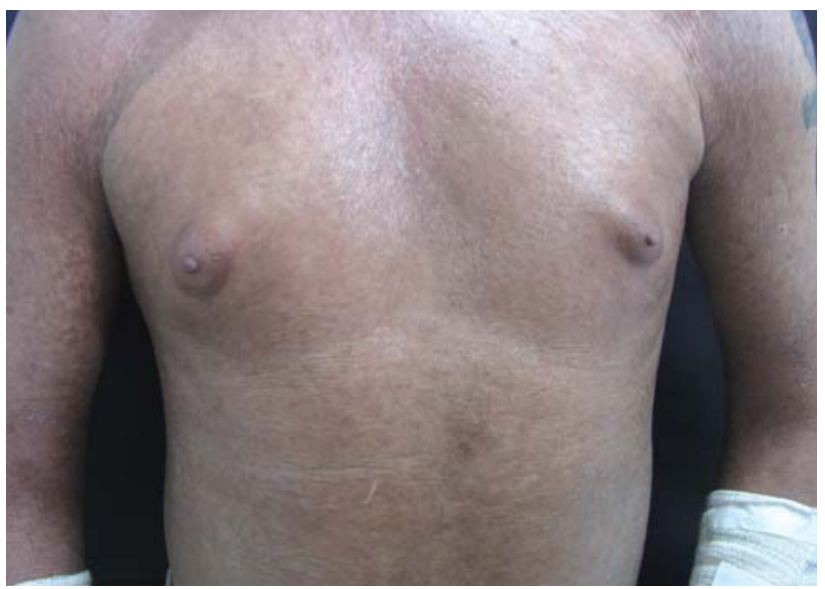

FIGURE 1: Hyperpigmentation and diffuse cutaneous thickening, sparing the nipples

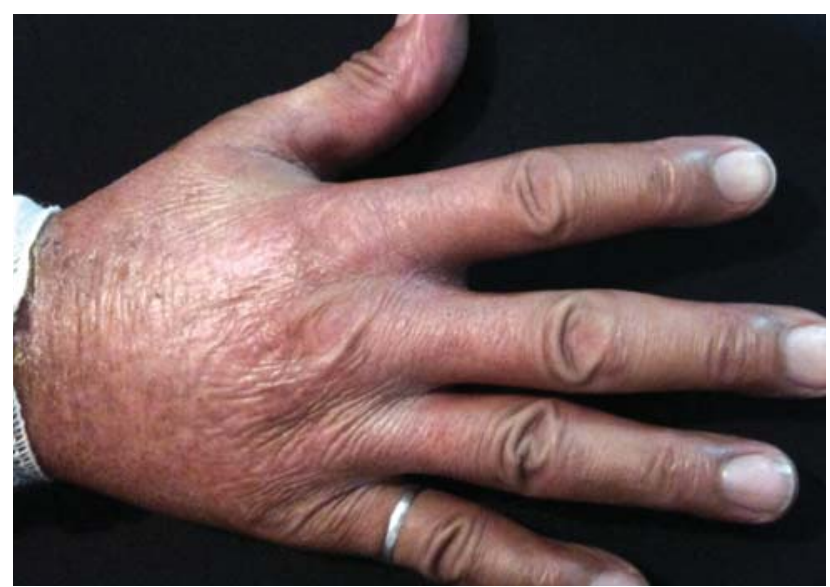

FIGURE 2: Increase in hand volume without thickening or sclerodactyly - characteristic of diffuse cutaneous systemic sclerosis

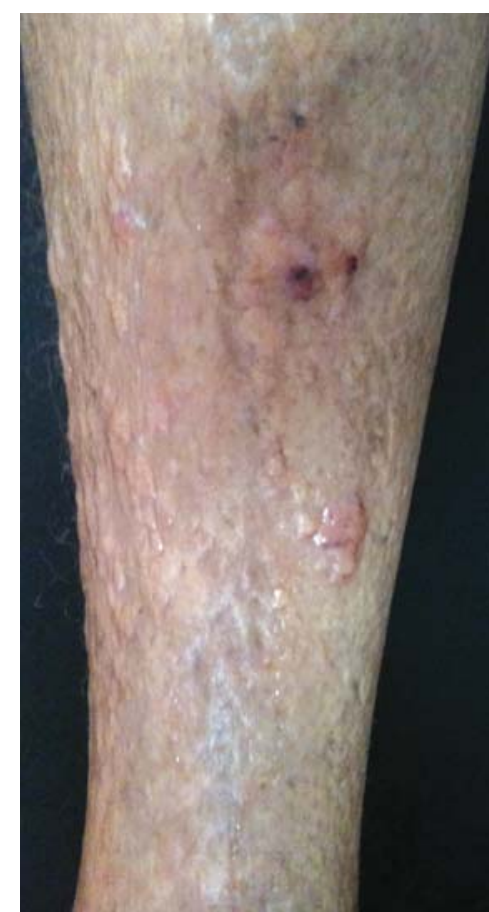

Figure 3: Tense bullous lesions and exculcerations, predominantly in the lower limbs

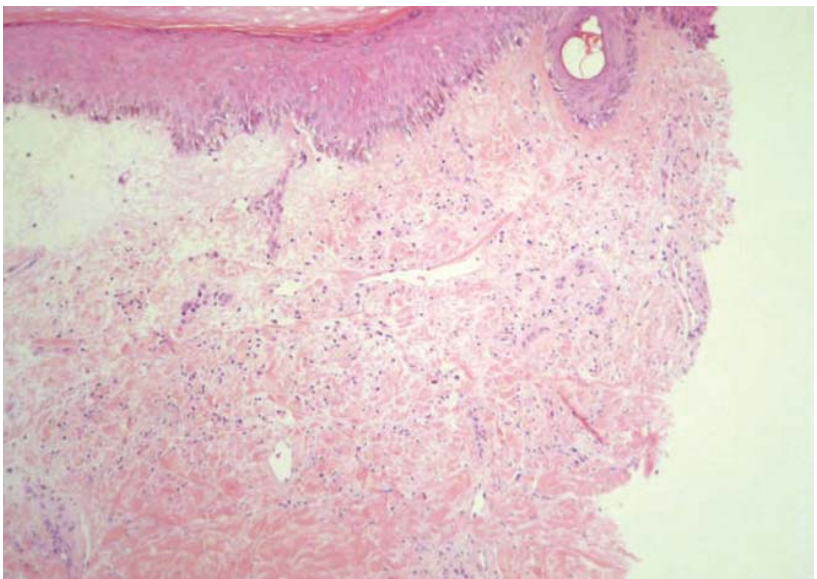

FIGURE 4: Subepidermal edema forming multiocular bullae, collagen compression and incarceration of annexes

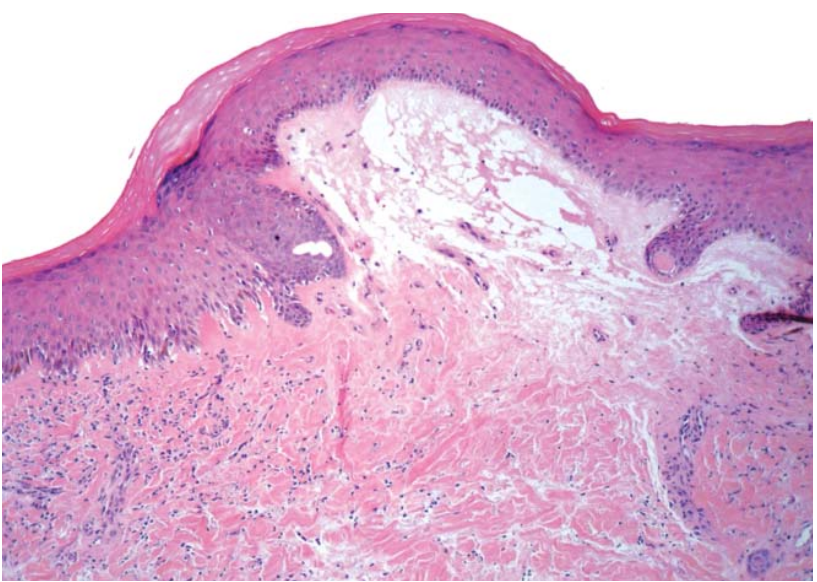

FIGURE 5: Lymphangiectasia 


\section{DISCUSSION}

Here, we describe an atypical case of systemic sclerosis in its diffuse form, an exuberant, acute, serious cutaneous condition involving rapid progression, with formation of bullae, an infrequent finding, without presenting any specific systemic changes. It is not clear why the patient developed such a disproportion between the cutaneous and systemic condition but we believe that the continuing preservation of organs during the evolution of the patient can be explained by the early therapeutic intervention. Initially, other diagnostic hypotheses were considered for the exceptional nature of the case, like scleromyxedema, discarded following the histopathological analysis and other scleroderma syndromes through occupational exposure (chemical agents such as vinyl chloride, bleomycin, silica), discarded due to the lack of an epidemiological context of exposure.

The formation of bullae has been described in all types of scleroderma and it is a rare finding. In this case, the bullae resulted from the subepidermal edema brought about by lymphangiectasias, secondary to fibrosis and lymphatic obstruction. ${ }^{3,4}$

The ANA fine speckled cytoplasmic pattern found can be associated with the antibody anti-histidyl t RNA synthetase (Jo-1), an antibody indicating polymyositis in adults and rarely reported in dermatomyositis. ${ }^{5}$ However, due to a lack of clinical data reinforcing this association in the exam of the patient in question, such as proximal muscle weakness, cutaneous lesions that are typical or indicative of muscular lesions, we consider this hypothesis unlikely. In most cases, the clinical relevance of the (recently reported) ANA cytoplasmic pattern is not defined, and other anti-tRNA synthetase antibodies can generate the same pattern. Drawing on the clinical situation described, the expected ANA pattern would be the nucleolar speckled one, associated with the antibody anti-RNA polymerase I, which corresponds to the diffuse form of systemic sclerosis.

The mucin finding in this case should not lead us to regard the mucinosis as primary but rather, as secondary to the exacerbated inflammatory process the patient developed, with the stimulation of mucin production by the fibroblasts. It is an extremely rare finding in scleroderma and is more common in systemic erythematosus lupus and dermatomyositis. ${ }^{6,7}$

Treatment for cases of extensive cutaneous conditions that progress rapidly can be carried out with cyclophosphamide, with or without another immunosuppressive agent, including mycophenolate mofetil or azathioprine. Another treatment option is the administering of rituximab. ${ }^{8}$ After 5 cyclophosphamide pulses, the patient experienced partial improvement in the cutaneous sclerosis, multiple hospitalizations due to infection, still without the specific systemic manifestations of the disease, perhaps on account of the early and aggressive treatment.

Prognosis is linked to affected organs in cases of systemic disease and some laboratorial markers. The presence of renal involvement (progressive loss of renal function or proteinuria over $3.5 \mathrm{~g} /$ day or cellular cylinders in urine), cardiac involvement (cardiac insufficiency, pericarditis or electrocardiographic changes) and pulmonary involvement (pleurisy, pulmonary hypertension, fibrosis or reduced diffusion capacity), at the time of diagnosis, are indications of worse prognosis. Esophageal, intestinal, muscular and joint involvement; the presence of the Raynald phenomenon; hypertension; hypergammaglobulinemia (as shown in this case); and positive rheumatoid factor, are not linked to bad prognosis. In males who are over 50 and experience an increase in ESR, as in the case of the patient in question, it is associated with lower survival rates. ${ }^{9}$ A periungual capillaroscopy showing the presence of devascularization can be a predictor of greater severity of the systemic scleroderma, entailing a greater link with visceral (rather than cutaneous) involvement ${ }^{10}$ In the case described, the capillaroscopy showed hairpin-shaped capillary loops, without any signs of devascularization, reaffirming the fact that, to date, there has been no systemic involvement. $\square$ 


\section{REFERENCES}

1. Callen JP, Jorizzo JL. Dermatological Signs of Internal Disease. 2nd ed. Philadelphia: WB Saunders; 1995. p. 21-30.

2. Sontheimer RD, Provost TT, editors. Cutaneous manifestations of rheumatic diseases. Philadelphia: Lippincott Williams \& Wilkins; 2003. p. 233

3. Tuffanelli DL. Localized scleroderma. Semin Cutan Med Surg. 1998;17:27-33.

4. Rencic A, Goyal S, Mofid M, Wigley F, Nousari HC. Bullous lesions in scleroderma. Int J Dermatol. 2002;41:335-9.

5. Dellavance A, Júnior AG, Nuccitelli B, Taliberti BH, Mühlen CAv, Bichara CDA, et al. 3. Consenso Brasileiro para pesquisa de autoanticorpos em células HEp-2 (FAN). Recomendações para padronização do ensaio de pesquisa de autoanticorpos em células HEp-2, controle de qualidade e associações clínicas. Rev Bras Reumatol. 2009;49:89-109.

6. Rongioletti F, Gambini C, Micalizzi C, Pastorino A, Rebora A. Mucin deposits in Morphea and systemic Scleroderma. Dermatology. 1994;189:157-8.

7. Martin-Bracciani N, Cogrel O, Beylot-Barry M, Ly S, Doutre MS, Beylot C. Strip papular mucinosis associated with systemic sclerosis. Ann Dermatol Venereol. 2004;131:361-4.

8. Manno R, Boin F. Immunotherapy of systemic sclerosis. Immunotherapy. 2010;2:863-78.

9. Braverman IM. Skin signs of systemic disease. 3rd ed. Philadelphia: Saunders; 1998. p. 255-377.

10. Skare TL, Esmanhotto L; Casnoch C, Silva MB. Nail fold capillaroscopy and systemic scleroderma severity. An Bras Dermatol. 2008;83:125-7.

\author{
MAILING ADDRESS: \\ Paula Renaux Wanderley Caratta Macedo \\ Avenida 28 de setembro, 77 \\ 20551-080 - Vila Isabel \\ Rio de Janeiro - RJ \\ Brazil \\ Email:paula_renaux@yahoo.com
}

How to cite this article: Macedo PRWC, Silva ANCMM, Gripp AC, Alves MFGS, Klumb EM. Diffuse systemic sclerosis with bullous lesions without systemic manifestations. An Bras Dermatol. 2013;88(6 Suppl 1):S78-81. 